"This is the peer reviewed version of the following article: Cockayne, DG, Ruez, D, Secor, AJ. Thinking space differently: Deleuze's Möbius topology for a theorisation of the encounter. Trans Inst Br Geogr. 2019; 00: 1- 14, which has been published in final form at https://doi.org/10.1111/tran.12311. This article may be used for non-commercial purposes in accordance with Wiley Terms and Conditions for Use of Self-Archived Versions."

\title{
Thinking space differently: Deleuze's Möbius topology for a theorisation of the encounter ${ }^{1}$
}

Daniel G. Cockayne

D epartment of G eography and Environmental Management, University of Waterloo

Derek Ruez

Space and Political Agency Research G roup, Tampere University

AnnaJ. Secor

D epartment of G eography, University of Kentucky

\begin{abstract}
:
The relation between difference and space has long been and continues to be an animating problem in theoretical and political conversations across the discipline of geography, including in much recent work on encounter. In this paper, we make the case for the value of a less explored angle on space in D eleuze's work, which we call the topologies of space-as-difference. We highlight the Möbius strip as a central figure in his ontological system, and we show the significance of this topological structure both for understanding key D eleuzian concepts, such as the virtual and actual, and for understanding space and difference in productive ways. We demonstrate this by showing how D eleuzian topologies of difference enable us to further theorise the encounter - a key theme in recent geographical scholarship - as spatial and embodied, connecting up with material feminism and work on the skin, touch, and breath. We suggest that D eleuze's concept of space-as-difference thus contributes to the intensification of relational and topological approaches to space that are currently shaping the discipline.
\end{abstract}

\section{Keywords:}

body, D eleuze, difference, encounter, materialism, space, topology

\section{Acknowledgements:}

The authors would like to thank Simon Naylor and three anonymous reviewers for their critical engagement and support.

\footnotetext{
${ }^{1}$ This is a self-archived post-print. Please see and cite the published version: Cockayne, D. G., Ruez, D., \& Secor, A. J. (2019). Thinking space differently: Deleuze's Möbius topology for a theorisation of the encounter. T ransadions of the Institute of B ritish G eographers. https:/ / doi.org/ 10.1111/ tran.12311
} 


\section{INTRODUCTION: ENCOUNTERING SPACE AND DIFFERENCE}

The problems and possibilities of encounter resonate across large swaths of geographic scholarship (Wilson, 2017). Much research has examined the effects, affects, and implications of particular encounters in specific contexts, including, for example, research on "fleeting encounters" across difference in a diverse urban neighbourhood (Ye, 2016) or "middle class encounters with poor subjects" (Lawson \& Elwood, 2014, p. 210). Scholars have also critiqued encounter as a normative idea that allows liberal-multicultural understandings of encounter to elide questions of power and inequality and, thereby, to underwrite racialised violence and precarity (e.g., Catungal, 2013). There are also theoretical deployments of encounter, exemplified by Katherine McKittrick's (2011, p. 950) work, in which encounter becomes a conceptual tool for thinking relationally in ways that resist the epistemologies of "bifurcation-segregation" that can further naturalise dispossession and violence. Speaking to these entangled genres of research, our aim is to develop an account of the Möbius topology in G illes D eleuze's work that invites geographers to approach the encounter as simultaneously a geohistorical production and an immanent spatial event through which difference continually emerges.

In order to do so, we build on recent geographical scholarship that approaches lived space as topological and emergent, less as a grid than as a bending, folding, stretching surface (Allen, 2011; Martin \& Secor, 2014). Specifically, we burrow down into what Arun Saldanha calls D eleuze's "revolutionary topology" (2017, p. 196), a perspective that offers an understanding of space-asdifference that can help us to theorise such central geographical concepts as embodiment and encounter. Thus, we situate our account in relation to long-standing traditions of work on the spacedifference nexus in feminist, queer, Black, and other critical geographies, which include, for example, the spatial articulation of difference and power that produces the violence of racialisation and heteronormativity (Gilmore, 2002; McK ittrick, 2006; O swin, 2010; Ruddick, 1996) and the spatial contingency of identity and otherness as matters of in- or out-of-place-ness (Ahmed, 2000; Cresswell, 2004). Indeed, many geographers have examined how difference and space could be considered coextensive or mutually constituted, and the idea of space-as-difference reverberates across geographic scholarship (Cockayne et al., 2017b; D oel, 2000; Jacobs \& Fincher, 1998; Massey, 2005; McD owell, 1999; Valentine, 2007). Moving beyond utopian conceptualisations of the encounter as necessarily generative of positive understandings of difference (Valentine, 2008) - a notion often underwritten by the assumptions of liberal and representational cosmopolitan politics - geographers continue to see the encounter as a way to think through what happens at meeting points and contact zones, whether they be in physical or in digital spaces (A skins \& Pain, 2011; Cockayne et al., 2017a). Yet arguably, the encounter remains undertheorised, leaving open a series of questions around precisely how key terms like space, difference, and embodiment could be conceptualised (Wilson, 2017; Wilson \& D arling, 2016). We respond to these questions by foregrounding the (im)materialities of embodied encounter and showing how a topological conception of spatiality provides a way to grapple with recurring questions about how the new does and does not emerge in an encounter.

We also offer this account, in part, as a contribution to D eleuzian socio-spatial theory, where work has tended to emphasise ontological flatness, immanent multiplicities, or assemblage (Anderson \& McFarlane, 2011; Anderson \& Wylie, 2009; D ewsbury, 2011; D ewsbury \& Thrift, 2005; D oel, 1999; Marston et al., 2005; Roberts, 2018). These frameworks are rightly central to any understanding of D eleuze and have provoked much critical and creative work. Nevertheless, there are risks in engaging with D eleuzian thought that we wish to address at the outset. There is a danger that, as some critics suggest, D eleuze is interpreted as denying dialectical thought wholesale - thereby ignoring how the dialectic is central to D eleuzian metaphysics - and thus disallows both the possibilities of an oppositional stance toward the present and an event that would transcend what already is (MacFarlane, 2017). While our account of the topologies of space-as-difference complicates that critique, there are 
some readings of D eleuze that tend to capture his insights in a univocal "canon of joy" and thereby reduce "his rigorous philosophy to the mutual appreciation of difference, openness to encounters in an entangled world, or increased capacity through synergy" (Culp, 2016, pp. 2, 7). We also seek to avoid a tendency toward what Weheliye calls "orthodox D eleuzianism, which insists on transforming Deleuze into a great thinker by reading him exclusively within the western European philosophical tradition" (2014, p. 47). To respond to these challenges, we show how D eleuze's Möbius topology, with its continual repetitions of seemingly dualistic terms (e.g., the virtual and actual), resists a retreat to either transcendence or univocal multiplicity, and instead operates as a non-dualistic dualism between the dual and the multiple. In this way, D eleuze situates a dialectic at the centre of his thought. He does so not in order to produce a reductionist form of dualistic thinking but in order to put it into conversation, to put it in the place of a problem (Smith, 2001). This dialectic remains, in an important sense, an immanent and positive one (Ruddick, 2008), but our attention to the topologies of space-as-difference highlights the role these dualisms have in the unfolding of encounters and in the actual curtailment of difference, while neither denying the force of that curtailment nor reducing reality to its outcomes. This leaves open the possibility for encounters among diverging perspectives on space and difference that may yet force thought in new directions.

In what follows, we first situate the paper in relation to recent work on the encounter as a way to show the critical potential of the topologies of space-as-difference for geographic scholarship. We then move through readings of The L ogic of Sense and D ifferenœ and R epetition that explicate the Möbius spatiality central to D eleuze's philosophy of difference. Though much of D eleuze's work examines spatiality explicitly (most obviously in D eleuze, 1988, 1992; D eleuze \& G uattari, 1987), these earlier works represent D eleuze's clearest exposition of his metaphysical system, and thus warrant further investigation with regard to the question of space, especially since a superficial reading might suggest (incorrectly, we argue) that D eleuze prioritises time over space in these texts. Following this articulation of how space functions as differenœ itself through the topological figure of the Möbius strip in Deleuze's metaphysics, we return to the encounter to show how it might be productively theorised through the lens of topology. We focus on the complex embodied topology of the encounter through a conceptual triad of skin, touch, and breathing that ultimately brings D eleuzian topology itself into an encounter with other approaches and other geographies.

\section{ENGAGING SPACE AND DIFFERENCE THROUGH THE ENCOUNTER}

In order to show more concretely the contribution that D eleuze still has to make to thinking space and difference, we draw on literature in geography on the encounter. Encounter can be thought of as the event of difference taking place (A hmed, 2000; Rovisco, 2010; Wilson, 2017; Wilson \& D arling, 2016). In a recent review, Helen Wilson (2017) conceptualises encounter as "a specific genre of contact" and a "distinctive event of relation ... within the remit of difference, rupture and surprise" (Wilson, 2017, p. 452; see also Askins \& Pain, 2011). Wilson demonstrates that a range of geographic scholarship has made the encounter central to the production of difference (see also Brown, 2008; Haldrup et al., 2006; Valentine, 2008). Yet, Wilson also notes that the encounter has so far tended to be undertheorised in geographic thought (see also Wilson \& D arling, 2016).

A focus on spaces of encounter or embodied encounters is not new (e.g., Ahmed, 2000; Leitner, 2012). However, our reading of Deleuze's topologies - of the virtual and actual, of the incorporeal and corporeal, among others - opens up new angles on the implications of spatiality and embodiment in encounters. Most often in the encounter literature we find that space refers to location or context, to the question of where encounters take place. Focusing most often on city spaces, the idea of encounter has been infused with a pluralist-democratic ethos deriving variously from the cosmopolitan urbanism of Jacobs (1961), considerations of actually-existing forms of conviviality (Amin, 2002; Gilroy, 2004), Habermasian ideals of public space as public sphere (Calhoun, 1992), and (more critically) the 
exclusionary practices of "public" spaces (Benhabib, 1996; D eutsche, 1996; Fraser, 1990; Mitchell, 1995). Recent research has challenged the myth that (urban) encounters necessarily foster respect or tolerance (Leitner, 2012; Valentine, 2008). Indeed, increasing attention is being paid to the dynamics of "bad encounters" that reiterate domination and provoke a range of reactions in response (Ahmed, 2010; Ruez, 2017). But regardless of its ethical valence, scholars have consistently theorised the encounter in relation to particular places and usually emphasise the geographical proximity of individuals (though see Cockayne et al. [2017a] who discuss remote digital encounters and Wilson [2016], who discusses remote textual and aesthetic encounters with cityscapes). Encounter has been taken to be inherently spatial but the spatiality of the encounter itself - what we'll discuss here in terms of its topological unfolding - has received much less attention.

We argue that a topological approach to space, developed through critical readings of D eleuze's writing, can productively open up new perspectives on the question of continuity and change that have been central to theorising encounters. In this we build on the work of scholars who have pointed to the need to consider encounter in broader spatial and temporal terms (Ahmed, 2000; Anderson, 2014; Lim, 2008; Wilson, 2017). Even as they posit something significant about the encounter - as a moment that, while never free of determination is not fully determined - they insist on the need to understand how encounters fold into other places and times. Their work suggests that encounters have a history and a future, and that understanding the spatiality of any particular encounter requires far more than just attending to the kind of location in which it is immediately happening. By showing how "multiple forms of mediation come together in encounters," Ben Anderson (2014, p. 79) presents us with an idea of the affective encounter as at once embodied, emergent, and tempered by the geographically and historically conditioned tendencies and orientations. These tendencies and orientations come together in the event of encounter, in which, as Jason Lim argues (2008), the actualisation of particular affects is shaped by but not exhaustive of a virtual field of available tendencies. This focus on the affective encounter thus brings the spae of interaction to the fore without letting the place of interaction drop out of the analysis. This opens onto recent work on topology in geography that conceptualises space through a non-deterministic, multi-causal lens and emphasises touch, the body, and the elasticity and permeability of space (Allen, 2011; D ixon \& Jones III, 2015; Lata \& Minca, 2016; Martin \& Secor, 2014; Secor, 2013).

While taking up Colin McFarlane's (2016) suggestion of the need for topological approaches to encounter, this paper points toward conceptions of topological space that also speak to broader conversations about the relational nature of space. Understanding space as relational has been immensely productive for human geographers working in a wide range of fields (see Elwood et al., 2017). Topology is not simply a synonym for relationality in general; neither is it a specific type of relation to be set against another, e.g., the topographical (Martin \& Secor, 2014). We mobilise D eleuze's topology to better attend to the problematic field through which relations emerge and unfold (or not). The topological space of the embodied encounter, which we develop in relation to the Möbius figure at the heart of D eleuze's thought, provides conceptual resources and provocations for geographic scholarship on encounter and socio-spatial theory more broadly. It is through the encounter - and a turn to materialist feminism - that we demonstrate what it means to think the topologies of space-asdifference. In order to develop this D eleuzian notion of topological space, in the next two sections we explore D eleuze's writing in The L ogic of Sense and D iffereno and Repetition. By locating space at the heart of D eleuze's most metaphysical works, we follow Saldanha's (2017) sense that a Deleuzian "geophilosophy" takes space as neither the ground for nor the object of analysis but rather as a condition for thought itself, and D oreen Massey's (2005, p. 40) argument for an idea of space, as open, relationally produced, and always under construction, what she calls "the sphere of possibility of heterogeneity." 


\section{SPATIALISING DIFFERENCE: DELEUZE'S MÖBIUS TOPOLOGY}

While our aim is to distil D eleuze's notion of space, we note that there are many points in his writing where he appears to prioritise time over space. Massey (2005) critiques this tendency to find dynamism within the temporal while casting space as inert. The L ogic of Sense begins with a consideration of time, and the ostensible topic of the book is the relationship between time and language; D ifference and Repetition opens with a discussion of three temporal syntheses that frame his discussion of emergence. This seeming prioritisation of time over space in these two works, we contend, is a question of focus and not one of omission. In this section, starting with The L ogic of Sense, we examine how D eleuze's metaphysics is one that prioritises space as well as time. We highlight D eleuze's use of spatial concepts (and how they pertain to his concept of difference), including, most notably, the topological figure of the Möbius strip but also other topological figures that include surfaces, lines, points, and distance. $\mathrm{Our}$ central argument in this section is that although D eleuze's two temporalities (Chronos and Aion) launch the development of thought in The L ogic of Sense, what is repeated throughout this work and others is the articulation of difference that ramifies the two sides of the duality. This relationship is a spatial figure (the Möbius topology), such that space is not just an attribute of existence but a dynamic force within D eleuzian ontology.

D eleuze's rethinking of the Platonic temporal dualism of Chronos and Aion at the beginning of Logic of Sense germinates a proliferation of paradoxically continuous antinomies. D eleuze assigns Chronos the spatial figure of the circle in which the only time is the present, in which existence ex tends itself and in which everything happens. This is the living present time of bodies, states of affairs, actions, and passions. He assigns to Aion the spatial figure of the line that divides itself infinitely into the past and future, always eluding the present. D istributed along this line is "pure becoming without measure," incorporeality, and non-existence (D eleuze, 1990, p. 1). Through this central dualism D eleuze locates being and becoming, bodies and incorporeal entities, causes and effects, substantives and verbs, the state of affairs and the event, genesis and sterility, denotation and expression (or sense), eating and speaking, lack and excess, solutions and problems, the actual and the virtual (in D ifference and Repetition), and more (e.g., snark/ Boojum!). These dualities, what he calls ramified heterogeneous series, are not interchangeable but are rather paradoxical distributions occurring in different arenas and even nested within one another. This means that the dualities operate differently, depending on where they are located within a "single" phenomenon. Though often thought as predominantly temporal, the two "sides" of the dualism are brought together as a simultaneously spatial and differential figure at the heart of D eleuze's metaphysics: a Möbius strip characterised as "the coexistence of two sides without thickness, such that we pass from one to the other by following their length" (Deleuze, 1990, p. 22). This properly Möbius topology is one whose surface "is also the frontier, the cutting edge, or the articulation of the difference between the two terms" (D eleuze, 1990, p. 28). Thought thus, the topological figure of the Möbius and this "articulation of difference" attain a synonymy in Deleuze's thought, allowing us to locate a concept of space-as-difference, in addition to time, at the heart of his metaphysics.

The significance of the dualities as distributed along the twisted surface of the Möbius is not the consistency of oppositional terms but their common coexistence and modes of inter- and intra-relation. First, D eleuze emphasises that the two sides are always in a relationship of heterogeneous disequilibrium and asymmetry. In each of the dualities, the second term is the incorporeal - that which lacks existence but instead inheres. For example, expression is a surface effect of the proposition; expression inheres within the proposition and cannot be understood to exist outside of it. At the same time, the second term is always in excess of the first: what is expressed (sense) is always in excess of what is denoted, the ideal event exceeds what happens, virtual multiplicities are in excess of their actualisation. And to further destabilise conventional notions of dichotomous relations, the second term serves as both one term in the duality (as an effect of the other term) and the frontier between them (as the quasi-cause of the other term), as that which articulates their difference. Thus sense is not 
only on the side of expression, as contrasted to the side of denotation, but also that which articulates the difference between the denoted and the expressed (Deleuze, 1990, p. 28).

Second, the "two sides" of the Möbius communicate in a relationship of complex double-causality, in which an admixture of bodies and states-of-affairs in the living present on the one side form the cause of incorporeal entities on the other. At the same time, though these incorporeal entities (language and sense being the primary examples) are described as effects, D eleuze also describes them as acting back upon bodies and states-of-affairs as what he calls the "quasi-cause." In a practical sense D eleuze is saying that sense is produced by our empirical circumstances - bodies and states-of-affairs, or the already-actualised world that we know and apprehend. But once caused, sense, though a "pure effect" (D eleuze, 1990, p. 124), surpasses that empirical beginning to form a transcendental field, plane of consistency, or surface that acts back upon those empirical circumstances as a quasi-cause. Sense is thus both and at once an effect and a quasi-cause. This is D eleuze's explanation for how language - and other complex systems like consciousness - appears to radically exceed its circumstances of production and reproduction. So on the one side of this dualism (Chronos, denotation, or bodies and states-ofaffairs) we have cause, and on the other (Aion, sense, or incorporeal entities) we have the quasi-cause. Neither term precedes the other but instead they exist in a relationship of asymmetrical simultaneity.

At the heart of D eleuze's ontology is therefore a spatial figure - a Möbius relation of continuity between opposites, accompanied by a spatial language that describes how sense is produced along the surface of the strip. In characterising the terms of the dualisms as two sides of a surface that are in a relation of "reversible continuity," D eleuze (1990, p. 340) makes it clear that these sides do not negate each other but rather relate to one another paradoxically. Following the edge or frontier between them, the logic of sense slides from one side to another, operating upon and functioning within both but without being a formal characteristic of either. This frontier, edge, or border is without any dimensionality of its own but functions to link the two divergent sides (or heterogeneous series) at the surface. This frontier both distinguishes the two sides and brings them into relation with one another, like a membrane that puts internal and external spaces into contact at the same time as being that which separates them. The frontier does not synthesise; it does not reunite the "sides" of Deleuze's dualism (for example, things and propositions) but rather articulates them through their difference.

Circulating endlessly between each distinct side, the edge of the Möbius creates the continuity of reverse and right sides. The frontier makes the heterogeneous series ramify; it makes one and the same event the expressed of the proposition and the attribute of things. Everything occurs doubly and simultaneously, though asymmetrically, on both sides of the Möbius: the event arises at once in being and in language, in the state of affairs (where the event crops up) and in the proposition (where the event subsists). G uaranteeing the convergence of the two sides but also making them endlessly diverge, the edge as "paradoxical element" goes by many different names: it is the aleatory point distributing the two series of the Ideal game; it is the question that articulates problems and solutions; it is sense ramifying signifier and signified, or nonsense articulating the duality of the esoteric word and the exoteric thing; it is the attribute (of the state of affairs) and the expressed (of the proposition); it is the event that occurs simultaneously in being and language. This paradoxical element is another name for the "quasi-cause" (discussed above) because it is immaterial - an effect of bodies and their mixture and yet it performs a causal function. And so in the endless regress of Deleuzian thought, the edge of the Möbius is itself a Möbius surface in which cause and effect reverse into one another.

D eleuze's spatial ontology brings into play topological concepts of surface, line, point, and distance. Just as "the relations among the elements, rather than the nature of the elements themselves, are the important aspects of a topological space" (Martin \& Secor, 2014, p. 423), the significance of the dualities is how they resonate with one another to create a topological space. Reflecting the basic topological definition of a spatial manifold as a surface, the double distribution of bodies and propositions across two continuous sides performs a "static genesis," producing the surface where 
"everything that happens and everything that is said happens or is said" (D eleuze, 1990, p. 132). The product of the mixing of bodies (actions and passions), topological surfaces are multiplied by diverse processes - "stretching, fragmenting, crushing, drying and moistening, absorbing, foaming, emulsifying, etc" (1990, p. 124) - and defined by a notion of "distance" that is not opposed to proximity but instead articulates divergent points by "affirm[ing] that which it distances" (1990, p. 173). D ivergence or disjunction are thus relations of "positive distance" in a flat world: "The idea of positive distance belongs to topology and the surface. It excludes all depth and all elevation, which would restore the negative and identity" (1990, p. 173; see also 1983, p. 2). D eleuze makes a simultaneous spatial and differential claim by creating a correspondence between difference and the positive distance affirmed by sense. The two sides of the Möbius resonate in and through their distanc-without-dimension, or difference, which is not a principle of exclusion, opposition, or contradiction but instead a means of resonance and communication.

Topology is not incidental to D eleuze's thought, but is rather its immanent structure. Space appears as a precondition on both sides of the single-sided figure. As the surface of actualisation, space is the incorporeal element within the state of affairs; as the topos of nomadic distributions, space is the generative and embodied field for the becoming of the event. This doubling of space seeds each side of the duality with its reverse and makes the spatio-temporal determination of bodies and propositions possible. Space thus proliferates in a D eleuzian regress: outside, at the surface, inside, and within each term again, space is both the form and the content of the Möbius topology that is the operator and structure of Deleuze's metaphysical system.

\section{SPACE AND DIFFERENCE IN THE VIRTUAL AND THE ACTUAL}

The spatial structure of asymmetrical topology, characterised by its Möbius figure and double-causality, persists across D eleuze's philosophical works despite shifts in vocabulary and emphasis. Here we develop the arguments made in the previous section by turning to D ifference and Repetition, in which the dualisms presented in the previous section are reframed in perhaps their most powerful and quintessentially D eleuzian form: the virtual and the actual.

D eleuze (1994) works through the Möbius dualism of the virtual and the actual throughout D ifference and Repetition to examine the general development of complex systems. D eleuze applies this dualism across multiple registers, including language, psychic organisation, and biological development, using each of their associated vocabularies to demonstrate how newness is able to emerge between the two distinct but interrelated registers (Smith, 2007). The virtual and the actual are an account of that which escapes empirical observation in the register of phenomenological experience and as necessarily beyond the bounds of representation, but without creating a fully transcendent category (e.g., Plato's eidos) that would exist as distinct from ideas and things as such. For example, roughly construed, D eleuze gives an account of the psychic encounter between the Self and the O ther such that the O ther exists on the "side" of the virtual, while the Self and the I exist on the "side" of the actual. The Self and the I are a set of appearances with nonetheless real effects; they are a result of the working out of underlying processes situated between the virtual and the actual. The 0 ther as a virtual expression of difference is neither oppositional nor antagonistic in D eleuze, and it does not play the role of an existential threat to the actual Self as it does in some other metaphysical systems. Y et these actual psychic constructs - the Self and the I - also cover over the virtual, presenting themselves as that which is necessarily given to experience. The actual therefore diverts attention away from the virtual, presenting itself as the only available and viable explanatory framework. D eleuze's claim is that in fact the actual cannot be understood without looking at the "swarm of differences" (1994, p. 50) that lies beneath the actual and that can only be accounted for through examining the virtual and the interaction between these two systems. 
It is tempting to view the virtual and the actual as distinct and separate, as a straightforward dichotomous dualism, in which the virtual is the primary term, and the actual is always subordinate to it. D eleuze constantly works against this reading. The virtual and the actual are in a circumstance of constant mutual constitution, with neither term taking priority over the other. D eleuze describes the overlapping of the virtual and the actual as comprised of two repetitions that are characteristic of each yet inseparable from one another: "we repeat twice simultaneously, but not the same repetition: once mechanically and materially in the breadth, and once symbolically and by means of simulacra in the depth; first we repeat the parts, then we repeat the whole on which the parts depend" (1994, p. 290). D eleuze states that both the actual and the virtual "come first"- like the quasi-cause in the previous section, both "sides" of the Möbius are primary - they are both and at once the primary term in his non-totalising, non-deterministic dualism - forming together an essential component of all phenomena. Rather than referring to virtual and the actual phenomena, it would therefore be more helpful to describe virtualising and actualising processes, since though the virtual (which D eleuze also calls both the ideal and the real) determines the actual, the actual forms its basis, and may also cover the virtual, limit it, and abolish its own foundations produced in collaboration with "deeper" virtual processes. The actual state of affairs describes how the immanent potentialities of the virtual resolve (or fail to resolve) themselves into determined qualities and extensities.

To outline the dynamic relationship between the virtual and the actual in his transcendental empiricism, D eleuze introduces the concepts of differentiation and differenciation. Differentiation refers to "the determination of the virtual content of an Idea," while differenciation refers to "the actualization of that virtuality into ["qualities or diverse"] species and distinguished parts" (1994, pp. 207, 210). D eleuze describes differenciation or actualisation in mathematical terms, as an "original process," or set of "local integrations" that are not opposed to the process of differentiation (1994, p. 209). In addition to the actualisation of species and parts that pertain to differenciation, D eleuze describes how differentiation has two aspects of its own - varieties of relations and singular points. He thus organises within each process two terms that are integrated, actualised, or solved through the dual process of different/ ciation. In terms of the spatial inflection embedded in these ideas, D eleuze states that "there is in general no quality which does not refer to a space defined by the singularities corresponding to the differential relations incarnated in that quality" and that "difference in quality [i.e., differenciated in the actual] is always subtended by a spatial difference" (1994, p. 210). Thus for D eleuze, in the process of becoming occurring between the virtual and the actual that he describes through differentiation and differenciation, singular points characterise a spatiality of the virtual that determines the Idea through differentiation, which then defines qualities or diverse species as they are actualised through the process of differenciation.

D eleuze describes spatiality in the virtual in terms of the underlying dynamisms of singularities and their relations without which the process of different/ ciation could not take place. In the example of the biological development of the embryo, D eleuze explains that "rather than discovering the more general beneath the less general, we discover pure spatio-temporal dynamisms (the lived experience of the embryo) with regard to the constituted parts and qualities, beneath the morphological, historical, anatomical, physiological and other characteristics" (1994, p. 215). Thus the space of the virtual is composed of "spatio-temporal dynamisms" that exist "beneath the actual qualities and extensities, species and parts" and yet in "strict complementarity" with them (1994, pp. 214, 217). This is the same spatiality as described in the previous section in terms of space on the side of becoming (the event): the topos of the nomadic distribution in which (pre-individual) singularities are condensed and precipitated. This virtual spatiality is both the condition for and the result of actualisation.

The "drama of actualization" is thus the working out of how these virtual spatio-temporal dynamisms produce, integrate, or differenciate particular space-times in the actual (p. 216). D eleuze writes that "spatial dramatization is played out on several levels: in the constitution of an internal space, but also in 
the manner in which that space extends into the external extensity, occupying a region of it," and that "everything is even more complicated when we consider that the internal space is itself made up of multiple spaces which must be locally integrated and connected" (1994, pp. 216-217). The internal space is not that of the spatio-temporal dynamisms themselves, but the beginning of their reciprocal working out with regard to the processes of differentiation and differenciation: the space

"corresponding to the differential relations and to the singularities to be actualized" (1994, p. 216). This actualisation is a process closely associated in spatial terms with the formation of an object or concept's limit or boundary defined both by what is interior and exterior to it and by how that object or idea is connected to others.

The politics of D ifference and Repetition are found in the philosophical challenge it poses to a dominant image of thought - a challenge that cannot but reverberate through socio-spatial theory. If the dominant images of space are space as location, as a (E uclidean or Cartesian) grid, as subordinate to time, and as empty, open, and available for appropriation (Massey, 2005), then the promise of a virtual conception of space as spatium is a challenge to unground that image, to find a new image, to create multiple images, or to find a sense of space - an imperceptible space that can only be sensed - that doesn't project any set of fixed assumptions in advance. It is possible to think of this promise in relation to the problematic potential that inheres in the encounter. Deleuze writes that in the process of actualisation, difference may be (though is not necessarily) denied, and the bare repetitions of sameness, and of representation, are allowed to emerge: "difference tends to deny or to cancel itself out in extensity and underneath quality" (1994, p. 223). Here we are returned to the "bad encounter" that (re)produces relations of domination and oppression by reifying toxic representations of difference while denying the pure difference of becoming.

The production of space and our embodied experience of it, we contend, are often characterised by these blockages of the virtual, by bare repetitions, by denials of potential, and by the violence of identity and representation. Thus the denial of difference, a particularly dogmatic image of thought that D eleuze calls "good sense," has profound material effects. D ifference forced into conformity with good sense might be an annulment of the possibility of difference in the encounter. In spatial terms, we might say that concepts of space that conform to good sense are an erasure of the potentiality of space, an elimination of the politics of space. Y et, D eleuze also writes that this foreclosure is never final, is never set in advance, and is not deterministic. This is the profound merit of his philosophy of transcendental empiricism and the non-dualistic Möbius system of the virtual and the actual in which both terms "come first" and neither is allowed to supersede the other. The cancellation of difference, of spatial potentiality in, for example, a dogmatic concept of absolute space as a transcendent Cartesian grid, is only a tendency that emerges in the process of actualisation. This tendency acts back upon the virtual as a suggestion, as one potential that has "worked out" in the past, however violent that process of working out has been. But difference continues to swarm beneath the erasure of difference in actualisation; it is still able to emerge, perhaps unpredictably and hesitantly, through those very processes since "not every distribution flows from good sense: there are distributions inspired by madness, mad repartitions" that are forms of "instantaneous, nomadic distributions, crowned anarchy or difference" (D eleuze, 1994, p. 224).

The challenge of building spatial theory from D eleuzian thought is to find the spatio-temporal dynamisms and structures that swarm beneath the set of appearances, the assumptions, and the shackles of representational thought that cancel difference in the process of actualisation. Our claim is that we might use this D eleuzian understanding of space as a way to theorise the encounter as characterised by a spatial topology. In a D eleuzian vein, this might be an attempt to force thought to access the imperceptible or insensible located beneath thought's image, beneath the established regime of sense - to access that which can only be sensed. This method denies complacent assumptions about space that position it in opposition to the dynamic multiplicities of the virtual. This is based on the 
conviction that difference is never wholly annulled through actualisation and that swarms of difference find their way to the surface. The failure of space to be confined to absolute and transcendental concepts attests to this as does the difficulty of accounting for the subject through rubrics of identity and representation.

\section{TOPOLOGY, BODY, ENCOUNTER}

How does a D eleuzian idea of space-as-difference, apprehended in terms of a Möbius topological relation, help us to think of the encounter as embodied and spatial? D eleuze describes the encounter as that which is foundationally opposed to recognition and the logic of representation. He refuses to view the encounter from a liberal point of view - one of a meeting of multicultural individuals through an implicitly combative or oppositional frame that through a rational exchange realise that their differences actually mean little. Rather than viewing the encounter as something that occurs between two preexisting individuals - a primarily anthropocentric hubris - D eleuze sees the encounter as a function of individuation - a differentiation that does not presume the presence of fully formed or even human individuals in advance, but that cuts perhaps across both scale and substance and could apply to many different kinds of bodies. The encounter for D eleuze is what happens, it is a catalyst, that which is productive of a transformation or becoming, it is what forces us to think. Deleuze writes: "something in the world forces us to think. This something is an object not of recognition but of a fundamental encounter. ... It may be grasped in a range of affective tones: wonder, love, hatred, suffering. In whichever tone, its primary characteristic is that it can only be sensed" (1994, p. 139). Deleuze's encounter is different from the liberal writings on encounter because of how he understands difference and otherness through a generative rather than oppositional and individualistic lens. D eleuze views otherness as that which populates a given field with structure, which, though imperceptible, gives that field the ability to function, or to make something happen. Thought through this lens, the encounter is foundationally generative and emergent, characterised by the play of virtual and actual and the doublecausality described above.

Synthesising the insights of a range of important work on encounter, including her own, Wilson notes that "encounters make difference" (2017, p. 455). Deleuzian understandings of difference can simultaneously complement and refract this point by showing how difference-in-itself emerges through the encounter, but also how the encounter often resists or actively nullifies difference, for example, by producing limiting images of difference through the lenses of liberal multiculturalism or conservative ethno-nationalist identity politics (Cockayne et al., 2017b). G oing further, situating the encounter topologically along the surfaces of the Möbius shows that the encounter is at once, nondeterministically, and asymmetrically actual and virtual, with priority given to neither term. Theorising the encounter as a process of actualisation encourages us to examine how its empirical spatiotemporalities - including the location where the encounter takes place and the "differences" that it calls forth - are formed through the creation of limits or boundaries that define what is interior and exterior and connect this encounter to others. At the same time, theorising the encounter as a process of virtualisation encourages us to examine the spatio-temporal dynamisms of the event - its potentialities, multiplicities, and its elsewheres. Recognising the endlessly dynamic topological relation of the virtual and actual can help us to conceptualise the already broadly held sense that encounters are conditioned but never fully determined. The encounter unfolds materially in the world at the same time as it enfolds geo-historically situated meanings. This is what Deleuze explains as the complex double causality of bodies and the incorporeal in The L ogic of Sense; it is also what Karen Barad (2007) calls the "entanglement of matter and meaning." Understanding the encounter in this way thus holds open and puts into relation both the immanent spatiality of the event and its geo-historical "location."

Materiality and embodiment have each been important themes in work on encounter, but the topology of space-as-difference pursues these questions with a twist, by attending to the (im)materialities of the 
body as a spatial figure - in terms of the skin, touch, and breathing, which exemplify how the encounter operates like the "edge" of the Möbius, both joining and separating its elements. To bring forth the body without reproducing dualisms of mind/ matter and mind/ body (indeed, while actively undermining such dualisms as they are traditionally posed), we turn to materialist feminists who view the body as a folding, incorporating externality at the same time as its affective capacities unfold outwards to the world (Braidotti, 2011a, 2011b; Alaimo \& Hekman, 2008; see also Deleuze, 1988). We thus approach embodiment as topological, characterised by its problematic potentials, uneven connections, and asymmetric simultaneities. For example, we usually understand the skin as something that separates, but when thought topologically in terms of uneven connection, we can ask, does the skin "belong" to the organs it keeps in any more than the atmosphere that it keeps out? Asking this question allows us to draw attention to the skin as a surface that serves as a contact zone or an interface that cannot be discreetly separated from its immediate surroundings or from the interiority that it demarcates between two entities, in which a neatly delineated outside is no longer possible to pinpoint (see also Colls \& Fannin, 2013). Further, the corporeality of the skin is conditioned by non-present, incorporeal relations (geo-historical, intersubjective, and linguistic) that allow for its particular mode of emergence - that is, for the skin's conceptual constitution as racialised, sexualised, and classed. We draw here on Gilbert Simondon (2017) - a writer who strongly influenced D eleuze - to theorise semipermeable membranes, like skin or the edge of the Möbius, as not only containing or keeping out certain entities, or as already established and fully formed boundaries, but as themselves process of individuation or differenciation. The skin thus functions as "the twisting of the Möbius strip, the torsion or pivot around which the subject is generated" (G rosz, 1994, p. 35).

Skin is both intensely intimate - where we touch and are touched - and dramatically public when understood as the site where racial and other differences are marked. Frantz Fanon calls racism a process of "epidermalization of inferiority" in which skin translates relations of domination across the surface of the body and the unconscious (1967, p. 11; for more psychoanalytic understandings, see Anzieu, 2016; Cavanagh et al., 2013). The fetishistic fixing of difference on the visible skein of the body becomes a way to shore up the boundaries between self and other, to expel from the body what is undesirable and to fix it within a visible, racialised order where the surface of the body is taken to reflect some essential truth that justifies existing relations of oppression and domination (Kristeva, 1982; Tate, 2001). By securing the skin as boundary, casing, and inscription (that is, through epidermalisation), racism subordinates "a swarm of differences, a pluralism of free, wild or untamed differences; a properly differential and original space and time" to representation, limitation, and opposition (Colebrook, 2013; D eleuze, 1994, p. 50; Saldanha, 2007; Swanton, 2010). Through the skin we can think the topology of the encounter as a differential loop in which the multiplicities of self and other, surface and depth operate across the twist of the Möbius. In the encounter, intensities (qualities, speeds, relations, rates of change) are distributed along the surface of the body, an interface that cannot be discretely separated from its immediate surroundings or from the interiority that it demarcates (see also Colls \& Fannin, 2013).

If the skin itself folds inward and outward, this is because it materialises the encounter through the sensation of touch; "the skin registers how bodies are touched by other bodies" (Ahmed \& Stacey, 2001, p. 11). Touch implies a meeting of surfaces and is therefore inherently bound up with some kind of encounter. In Erin Manning's words, "touch, alongside politics, invents by drawing the other into relation, thereby qualitatively altering the limits of the touched-touching bodies" (2007, p. xv). Because our bodies touch both themselves and other non-human bodies in ways and places that are sometimes invisible (Colls, 2012; Dixon \& Jones III, 2015; Irigaray, 1985), explorations of touch challenge the primacy of sight and seeing as ways of knowing in Western epistemologies (D ixon \& Straughan, 2010; Hetherington, 2003; Pallasmaa, 2012; Paterson, 2006). By connoting a bringing into contact of space with itself, the dynamics of touch suggest that space cannot be conceptualised either topographically or 
as a flat and immovable surface. Touch (like the Möbius) undermines the distinction between separation and connection.

G eographers and others have moved these debates into the figural, examining territorial, national, and other borders as a kind of skin, thus conceptualising touch in a more geopolitical sense (Billé, 2018). This might allow us, through the concept of touch, to contort and twist traditional understandings of the space and scale of the encounter, and to imagine how touch functions across national and international contexts to the personal, embodied, and molecular levels (Barad, 2012; Mountz \& Hyndman, 2006; Pain, 2015). Irrespective of whether we consider touch in positive or negative terms, as a literal bodily touch or a figural touch of the colonialist state, touch produces a set of resonances, and puts heterogeneous series into communication. A D eleuzian topology of touch is productive for work such as this that aims to keep both the fleshy entanglements of the haptic and its geohistorical conditions in play. Rather than collapsing back into a complacent empirical immediacy (D eleuze's critique of phenomenological approaches), the virtual-actual Möbius of touch-as-encounter demonstrates how the "sense" (geopolitical, colonial, or otherwise) that inheres in touch (the sensible) is at once an effect of that material encounter and a condition of its emergence.

Just as a topological engagement with skin and touch can twist understandings of the typically expected space and scale of the encounter, attention to breathing can further problematise the spatial entanglement of the encounter. In the literature on encounter, there is a largely metaphorical use of breathing to argue for a less prescriptive study of encounters that allows for distance, ambivalence, and "room to breathe" (Ye, 2016). Though working precisely toward an ethics of encounter, Emmanuel Levinas (1981) similarly deploys breathing as a model of encounter that preserves the other as other. In that sense, inhalation is a taking-in of and an opening-up to the other that nevertheless leaves the alterity of the other intact. Understood in topological terms, breathing troubles notions of interiority and exteriority and draws attention, as well, to the broader ecologies and atmospheres through which selves and others are created, bounded, and sustained (or not) (Conradson, 2005). Inhaling and exhaling, as well as the possibility of their violent abrogation, continually remake a body in relation to the material contents and conditions of the air one breathes. However, that air - and the broader ecologies one encounters - is not everywhere the same. As work on environmental injustice and environmental racism shows, who breathes what kind of air and where become questions of inequality, precarity, and the spatialities of racialisation (D illon \& Sze, 2018; Pearce et al., 2006; Pulido, 2000). Breathing as encounter is conditioned by the systems and processes that produce the air, its varying qualities, and their distributions. The conditions of encounter that situate people so unevenly are central to the encounter as such, even as they cannot exhaust it (A hmed, 2000). The topological relation of the virtual and the actual provides a way to think the conditioned but not fully determined character of encounter, where those conditions can be understood as actualisations that cover the difference out of which distinct kinds of relations could have been and may yet be made.

In that sense, the space of encounter is less a meeting zone, containing already-individuated bodies that can be plotted like the points of a curve on a flat surface, than it is a multiplicity produced dynamically in the twist where body- atmospheres coagulate or dissipate. If our bodies are constituted at least in part by the air we inhale, the light radiation that our skin both absorbs and reflects, and the closeness and distance we manage with and between those around us, then one possible way to imagine the complexity of the space of encounter is through a Möbius topology. D rawing on the relationship D eleuze posits between the virtual and the actual, there is no particular element that "comes first"; difference is produced in the encounter, yet the encounter would not be possible without the differences that swarm beneath it. The empirical circumstance of bodies coming together or apart in space is simultaneous with the embryonic becoming in which newness might (though often does not) emerge. 
While Junjia Ye (2016) is right to raise questions about the prescriptivism and, even, moralism of some encounter research, there remains, we think, an ethics to encounter that cannot be reduced to the competing moralisms of liberal multiculturalism and conservative identity politics. Like Elizabeth G rosz, we find in Deleuze's work a kind of ethics immanent to "how we live and that can be developed only in our encounters with others and with the world and its forces" (Grosz, 2017, p. 132). This can unfold an ethics of immanent thriving, of the sort that G rosz outlines, but it can also call forth (without opposition) an ethical refusal to "undo the problem of difference in the encounter by creating territorial and racialized enclosures that reassert a spatial logic in which there is a strict and recognizable difference between 'us' and 'them'" (G ökarksel \& Secor, 2018, p. 14; also see Lim, 2008).

D eleuze is not the only thinker whose thought may be harnessed to the project of theorising the encounter as topological and embodied. Lacan, Levinas, Merleau-Ponty, Fanon, and Irigaray are all thinkers whose work provides resources for such thought, and they inform some of the scholarship we refer to above. O ur goal is not to ignore the real and meaningful differences between these theorists D eleuze criticises and builds on many of the positions held by these writers - but rather to plumb these diverse engagements for potential overlaps, allegiances, and connections. We thus do not wish to level or "over-code" the diversity of these approaches or to blanket them in D eleuzian critique. Our goal is rather to demonstrate that there is a topological element in Deleuze's thinking on difference that can help us to theorise encounter as not only geographically and historically located but also as an embodied, spatial event. Functioning as the edge of the Möbius, the encounter pulls heterogeneous series - of interiors and exteriors, bodies and incorporeal entities, sensibility and sense - into contact while also functioning as that which distinguishes them. By understanding the encounter in terms of a D eleuzian topology of space-as-difference, we are thus able to foreground the dynamic interplay of the virtual and the actual in the encounter.

\section{CONCLUSION}

The topology of space-as-difference that we develop here offers a twist on some of the familiar coordinates of socio-spatial thinking. It seeks to complement and intensify the relational approaches to space that are productively shaping research trajectories in geography. Topology is an area where critically important work is being done across a range of theoretical and empirical approaches, not all of which are entirely consistent with our own (Allen, 2011; Joronen, 2016; Lata \& Minca, 2016; Martin \& Secor, 2014; Mitchell \& Kallio, 2017). We hope to find both productive resonances and discordances. Rather than offer a definitive account of what space is (as if we could), we see the value of our approach in the way it allows certain problems to be posed and questions to be raised.

We have found D eleuze's topology productive for thinking anew the recurring theme of so much work on encounter: the sense that encounters very often reinforce the conditions that produce them, even as the possibility persists that, precisely through an encounter, something new can emerge. A topology of space-as-difference provides a dynamism that allows for neither the reification of oppositional difference nor a collapse into sameness; by instead tracing how the irreducibility of pure difference operates across circuits of the virtual and the actual, our topological understanding of the encounter steers clear of essentialised renderings of either identity or universalism. We thus invite geographers to consider encounter as simultaneously a geohistorical production and an immanent spatial event through which difference continually emerges. Such is the surprise of the encounter - although there is no guarantee that such surprises will be good.

Thinking space in terms of a topological relationship between the virtual and actual puts the question of the simultaneity of continuity and change in a new light and allows us to pose the problem of how what happens folds back into what might (have) happen(ed). It also helps us grapple with the ethical dimensions of how bodies (their matter and meaning) are entangled in the encounter (Barad, 2007). 
This is important in the current political moment, where the limits of a liberal-capitalist multiculturalism have been made clear while the conservative identity politics of settler white supremacy and xenophobic ethno-nationalism persist and proliferate across many contexts. We do not suggest a kind of one-way street in which D eleuze, as master thinker, is simply applied to solve the problems of encounter. Instead, the very thinking of encounter that we have outlined suggests the importance, for Deleuzian thought, of encounters with other ways of thinking for forcing thought in new directions. We see, for example, a productive encounter with work in Black geographies, where McKittrick (2011) theorises encounter against epistemologies of bifurcation and segregation; these ideas resonate with aspects of D eleuze's thinking, even while they take thought to places that D eleuze did not go. Kathryn Medien (2019) has shown how D eleuze's affirmation of Palestinian life and resistance can reorient his anti-humanism in ways that align it with work in Black studies by foregrounding "the fallacies and violences of the category of Man via an affirmation of those humans expelled from Man's colonial orderings" (Medien, 2019, p. 12). Without necessarily retreating from the challenge to anthropocentrism that is also found in D eleuze's work, Medien's argument suggests the potential and, indeed, the necessity of grappling with the often erased modes of being human crafted by those expelled from "the category of Man-ashuman" so as to not simply repeat those expulsions and erasures in moves toward posthumanism and important work on more-than-human encounters (McKittrick, 2015, p. 3; Weheliye, 2014). The demands of the current moment call for intellectual and political work across a range of registers; our wager is that D eleuzian topology, while necessarily only one perspective among many other crucial ones, offers a dynamic and generative way of thinking space and difference that resonates with the political and ethical challenges of our times.

\section{REFERENCES}

A hmed, S. (2000). Strange encounters. New Y ork, NY : Routledge.

A hmed, S. (2010). The promise of happiness. D urham, NC: D uke University Press.

A hmed, S., \& Stacey, J. (2001). D ermographies. In S. Ahmed, \& J. Stacey (Eds.), T hink ing through the sk in (pp. 1-18). London, UK: Routledge.

Alaimo, S., \& Hekman, S. (2008). Emerging models of materiality in feminist theory. In S. Alaimo, \& S. Hekman (Eds.), Material feminisms (pp. 1-22). Bloomington, IN: Indiana University Press.

Allen, J. (2011). Topological twists: Power's shifting geographies. D ialogues in H uman G eography, 1, 283298. https:/ / doi.org/ 10.1177/ 2043820611421546

A min, A. (2002). E thnicity and the multicultural city: Living with diversity. E nvironment and Planning A , 34, 959-980. https:/ / doi.org/ 10.1068/ a3537

Anderson, B. (2014). E noountering affect. Burlington, UK: Ashgate.

Anderson, B., \& McFarlane, C. (2011). Assemblage and geography. A rea, 43, 124-127. https:/ / doi.org/ 10.1111/ j.1475-4762.2011.01004.x

Anderson, B., \& Wylie, J. (2009). On geography and materiality. E nvironment and Planning A , 41, 318335. https:// doi.org/ 10.1068/ a3940

Anzieu, D . (2016). The sk in-ego. London, UK: Routledge.

Askins, K., \& Pain, R. (2011). Contact zones: Participation, materiality, and the messiness of interaction. E nvironment and Planning D , 29, 803-821. https:/ / doi.org/ 10.1068/ d11109 
Barad, K. (2007). M eeting the universe halfway: Q uantum physics and the entanglement of matter and meaning. D urham, NC: D uke university Press.

Barad, K. (2012). On touching - the inhuman that therefore I am. D ifferenœe, 23, 206-223.

https:/ / doi.org/ 10.1215/ 10407391-1892943

Benhabib, S. (1996). The democratic moment and the problem of difference. In S. Benhabib (Ed.), D emocracy and difference: Contesting the boundaries of the political (pp. 3-18). Princeton, NJ: Princeton University Press.

Billé, F. (2018). Skinworlds: Borders, haptics, topologies. E nvironment and Planning D , 36, 60-77. https:/ / doi.org/ 10.1177/ 0263775817735106

Braidotti, R. (2011a). N omadic subjects. New Y ork, NY : Columbia University Press.

Braidotti, R. (2011b). N omadic theory. New York, NY: Columbia University Press.

Brown, G . (2008). Ceramics, clothing and other bodies: Affective geographies of homoerotic cruising encounters. Social and Cultural G eography, 9, 915-932. https:/ / doi.org/ 10.1080/ 14649360802441457

Calhoun, C. (1992). Habermas and the public sphere. In C. Calhoun (Ed.), H abermas and the public sphere (pp. 1-50). Cambridge, MA: MIT Press.

Catungal, J. P. (2013). Ethno-specific safe houses in the liberal contact zone: Race politics, placemaking and the genealogies of the AID S sector in global-multicultural Toronto. A CME, 12, 250-278. Retrieved from https:/ / acme-journal.org/ index.php/ acme/ article/ view/ 962

Cavanagh, S., Failler, A., \& Hurst, R. (Eds.) (2013). Skin, culture and psychoanalysis. Berlin, G ermany: Springer.

Cockayne, D ., Leszczynski, A., \& Zook, M. (2017a). \#HotForBots: Sex, the non-human and digitally mediated spaces of intimate encounter. E nvironment and Planning D , 35, 1115-1133.

https:/ / doi.org/ 10.1177/ 0263775817709018

Cockayne, D ., Ruez, D ., \& Secor, A. (2017b). Between ontology and representation: Locating Gilles D eleuze's 'difference-in-itself' in and for geographical thought. Progress in H uman G eography, 41, 580-599. https:/ / doi.org/ 10.1177/ 0309132516650028

Colebrook, C. (2013). Face race. In A. Saldanha, \& J. M. Adams (Eds.), D eleuze and race (pp. 35-50). E dinburgh, UK: Edinburgh University Press.

Colls, R. (2012). Feminism, bodily difference and non-representational geographies. T ransactions of the Institute of British G eographers, 37, 430-445. https:/ / doi.org/ 10.1111/j.1475-5661.2011.00477.x

Colls, R., \& Fannin, M. (2013). Placental surfaces and the geographies of bodily interiors. E nvironment and Planning A , 45, 1087-1104. https:/ / doi.org/ 10.1068/ a44698

Conradson, D . (2005). Freedom, space and perspective: Moving encounters with other ecologies. In J. D avidson, L. Bondi, \& M. Smith (Eds.), E motional geographies (pp. 117-130). Hampshire, UK: Ashgate. 
Cresswell, T. (2004). Plaœ: A short introduction. London, UK: Blackwell.

Culp, A. (2016). D ark D elezue. Minneapolis, MN: University of Minnesota Press.

D eleuze, G . (1983). N ietzsche and philosophy. New York, NY: Columbia University Press.

D eleuze, G . (1988). F oucault. Minneapolis, MN: University of Minnesota Press.

D eleuze, G. (1990). The logic of sense. New York, NY: Columbia University Press.

D eleuze, G. (1992). The fold: L eibniz and the baroque. Minneapolis, MN : University of Minnesota Press.

D eleuze, G. (1994). D ifference and repetition. New Y ork, NY: Columbia University Press.

D eleuze, G., \& G uattari, F. (1987). A thousand plateaus. Minneapolis, MN: University of Minnesota Press.

D eutsche, R. (1996). E victions: A rt and spatial politics. Cambridge, MA: MIT Press.

D ewsbury, J. D . (2011). The D eleuze - G uattarian assemblage: Plastic habits. Area, 43, 148-153. https:/ / doi.org/ 10.1111/ j.1475-4762.2011.01006.x

D ewsbury, J. D ., \& Thrift, N. (2005). G enesis eternal: After Paul Klee. In I. Buchanan, \& G . Lambert (Eds.), D eleuze and space (pp. 89-108). Edinburgh, UK: Edinburgh University Press.

Dillon, L., \& Sze, J. (2018). Equality in the air we breath: Police violence, pollution, and the politics of sustainability. In J. Sze (Ed.), Sustainability: A pproaches to environmental justice and social power (pp. 246-270). New York, NY: New York University Press.

D ixon, D ., \& Jones, J. P. III (2015). The tactile topologies of Contagion. T ransactions of the Institute of British G eographers, 40, 223-234. https:/ / doi.org/ 10.1111/ tran.12071

D ixon, D ., \& Straughan, E. (2010). Geographies of touch/ touched by geography. G eography Compass, 4, 449-459. https:// doi.org/ 10.1111/ j.1749-8198.2009.00299.x

D oel, M. (1999). Poststructuralist geographies. Edinburgh, UK: Edinburgh University Press.

D oel, M. (2000). Un-glunking geography: Spatial science after Dr. Seuss and Gilles Deleuze. In M. Crang \& N. Thrift (Eds.), Thinking space (pp. 117-134). London, UK: Routledge.

Elwood, S., Lawson, V., \& Shepard, E. (2017). G eographical relational poverty studies. Progress in H uman G eography, 41, 745-765. https:// doi.org/ 10.1177/ 0309132516659706

Fanon, F. (1967). The W retched of the E arth. New York, NY: Grove Press.

Fraser, N. (1990). Rethinking the public sphere: A contribution to the critique of actually existing democracy. Social T ext, 25, 56-80. Retrieved from https:/ / www.jstor.org/ stable/ 466240 G ilmore, R. W. (2002). Fatal couplings of power and difference: Notes on racism and geography. The Professional G eographer, 54, 15-24. https:/ / doi.org/ 10.1111/ 0033-0124.00310

Gilroy, P. (2004). A fter empire: M elancholia or convivial culture? New York, NY: Routledge. 
Gökarksel, B., \& Secor, A. J. (2018). Affective geopolitics: Anxiety, pain, and ethics in the encounter with Syrian refugees in Turkey. E nvironment and Planning C: Politics and Space.

https:/ / doi.org/ 10.1177/ 2399654418814257

G rosz, E. (1994). V olatile bodies. Bloomington, IN: Indiana University Press.

G rosz, E. (2017). The incorporeal: O ntology, ethics, and the limits of materialism. New Y ork, NY: Columbia University Press.

Haldrup, M., Koefoed, L., \& Simonsen, K. (2006). Practical orientalism - bodies, everyday life and the construction of otherness. G eografiska A nnaler: Series B, 88, 173-184. https:/ / doi.org/ 10.1111/ j.04353684.2006.00213.x

Hetherington, K. (2003). Spatial textures: Place, touch, and praesentia. E nvironment and Planning A , 35, 1933-1944. https:/ / doi.org/ 10.1068/ a3583

Irigaray, L. (1985). This sex which is not one. Ithaca, NY: Cornell University Press.

Jacobs, J. (1961). The death and life of great A merican cities. New Y ork, NY: Vintage.

Jacobs, J., \& Fincher, R. (1998). Introduction. In R. Fincher, \& J. Jacobs (Eds.), Cities of difference (pp. 125). New York, NY: G uilford University Press.

Joronen, M. (2016). Politics of being-related: On onto-topologies and 'coming events'. G eografiska A nnaler: Series B, 98, 97-107. https:/ / doi.org/ 10.1111/ geob.12093

Kristeva, J. (1982). Powers of horror: A n essay on abjection. New York, NY : Columbia University Press.

Lata, I. B., \& Minca, C. (2016). The surface and the abyss/ rethinking topology. E nvironment and Planning D , 34, 438-455. https:/ / doi.org/ 10.1177/ 0263775815622086

Lawson, V., \& Elwood, S. (2014). Encountering poverty: Space, class, and poverty politics. A ntipode, 46, 209-228. https:/ / doi.org/ 10.1111/ anti.12030

Leitner, H. (2012). Spaces of encounters: Immigration, race, class, and the politics of belonging in small-town America. A nnals of the A ssociation of A merican $\mathrm{G}$ eographers, 102, 828-846.

https:/ / doi.org/ 10.1080/ 00045608.2011.601204

Levinas, E. (1981). 0 therwise than being or beyond essenœ. The Hague, the Netherlands: Martinus Nijhoff.

Lim, J. (2008). Encountering South A sian masculinity through the encounter. In C. D wyer, \& C. Bressey (Eds.), N ew geographies of race and racism (pp. 223-237). Burlington, UK: A shgate.

MacFarlane, K. (2017). A thousand CEO s: Relational thought, processual space, and D eleuzian ontology in human geography and strategic management. Progress in H uman G eography, 41, 299-320. https:/ / doi.org/ 10.1177/ 0309132516644514

Manning, E. (2007). Politics of touch: Sense, movement, sovereignty. Minneapolis, MN: University of Minnesota Press. 
Marston, A., Jones, J. P. III, \& Woodward, K. (2005). Human geography without scale. Transactions of the Institute of British G eographers, 30, 416-432. https:/ / doi.org/ 10.1111/ j.1475-5661.2005.00180.x

Martin, L., \& Secor, A. (2014). Towards a post-mathematical topology. Progress in H uman G eography, 38, 420-438. https:/ / doi.org/ 10.1177/ 0309132513508209

Massey, D . (2005). For space. London, UK: Sage.

McD owell, L. (1999). G ender, identity, and place. Minneapolis, MN: University of Minnesota Press.

McFarlane, C. (2016). Encountering what is (not) there. In J. D arling, \& H. Wilson (Eds.), E noountering the city (pp. 229-232). Milton Park, UK: Routledge.

McKittrick, K. (2006). D emonic grounds: Black women and the cartographies of struggle. Minneapolis, MN: University of Minnesota Press.

McKittrick, K. (2011). On plantations, prisons, and a black sense of place. Social and Cultural G eography, 12, 947-963. https:/ / doi.org/ 10.1080/ 14649365.2011.624280

McKittrick, K. (2015). Yours in the intellectual struggle: Sylvia Wynter and the realization of the living. In K. McKittrick (Ed.), Sylvia W ynter: On being human as prax is (pp. 1-8). D urham, NC: D uke University Press.

Medien, K. (2019). D eleuze in Palestine. Theory, C ulture and Society. Advance O nline Publication. https:/ / doi.org/ 10.1177/ 0263276418816369

Mitchell, D . (1995). The end of public space? People's Park, definitions of the public, and democracy. A nnals of the A ssociation of A merican G eographers, 85, 108-133. https:/ / doi.org/ 10.1111/ j.14678306.1995.tb01797.xa

Mitchell, K., \& Kallio, K. P. (2017). Spaces of the geosocial: Exploring transnational topologies. G eopolitics, 22, 1-14. https:/ / doi.org/ 10.1080/ 14650045.2016.1226809

Mountz, A., \& Hyndman, J. (2006). Feminist approaches to the global intimate. W omen's Studies Q uarterly, 34, 446-463. Retrieved from https:// www.jstor.org/ stable/ 40004773

O swin, N. (2010). The modern model family at home in Singapore: A queer geography. Transadions of the Institute of British G eographers, 35, 256-268. https:/ / doi.org/ 10.1111/ j.1475-5661.2009.00379.x

Pain, R. (2015). Intimate war. Political G eography, 44, 64-73.

https:/ / doi.org/ 10.1016/ j.polgeo.2014.09.011

Pallasmaa, J. (2012). The eyes of the sk in: A rchitecture and the senses. Chichester, UK: Wiley.

Paterson (2006). Feel the presence: Technologies of touch and distance. E nvironment and Planning D , 24, 691-708. https:/ / doi.org/ 10.1068/ d394t

Pearce, J., K ingham, S., \& Zawar-Reza, P. (2006). Every breath you take? Environmental justice and air pollution in Christchurch, New Z ealand. E nvironment and Planning A , 38, 919-938.

https:/ / doi.org/ 10.1068/ a37446 
Pulido, L. (2000). Rethinking environmental racism: White privilege and urban development in Southern California. A nnals of the A ssociation of A merican G eographers, 90, 12-40.

https:/ / doi.org/ 10.1111/ 0004-5608.00182

Roberts, T. (2018). Resituating post-phenomenological geographies: Deleuze, relations, and the limits of objects. Transactions of the Institute of British G eographers, 1-13. https:/ / doi.org/ 10.1111/ tran.12280

Rovisco, M. (2010). Reframing Europe and the global: Conceptualizing the border in cultural encounters. E nvironment and Planning D , 28, 1015-1030. https:/ / doi.org/ 10.1068/ d0809

Ruddick, S. (1996). Constructing difference in public spaces: Race, class, and gender as interlocking systems. U rban G eography, 17, 132-151. https:/ / doi.org/ 10.2747/ 0272-3638.17.2.132

Ruddick, S. (2008). T owards a dialectics of the positive. E nvironment and Planning A , 40, 2588-2602. https:/ / doi.org/ 10.1068/ a40274

Ruez, D . (2017). 'I never felt targeted as an A sian... until I went to a gay pub': Sexual racism and the aesthetic geographies of the bad encounter. E nvironment and Planning A , 49, 893-910.

https:/ / doi.org/ 10.1177/ 0308518X 16680817

Saldanha, A. (2007). Psychedelic white. Minneapolis, MN: University of Minnesota Press.

Saldanha, A. (2017). Space after D eleuze. London, UK: Bloomsbury.

Secor, A. (2013). Topological city. U rban G eography, 34, 430-444.

https:/ / doi.org/ 10.1080/ 02723638.2013.778698

Simondon, G. (2017). $0 \mathrm{n}$ the mode of ex istence of technical objects. Minneapolis, MN: Univocal.

Smith, D . (2001). The doctrine of univocity: D eleuze's ontology of immanence. In M. Bryden (Ed.), D eleuze and religion (pp. 167-183). London, UK: Routledge.

Smith, D . (2007). The conditions of the new. D eleuze Studies, 1, 1-21.

https:/ / doi.org/ 10.3366/ dls.2007.1.1.1

Swanton, D . (2010). Flesh, metal, road: Tracing the machinic geographies of race. E nvironment and Planning D , 28, 447-466. https:/ / doi.org/ 10.1068/ d9507

Tate, S. (2001). 'That is my Star of D avid': Skin, abjection and hybridity. In S. Ahmed, \& J. Stacey (Eds.), Thinking through the sk in (pp. 209-222). London, UK: Routledge.

Valentine, G. (2007). Theorizing and researching intersectionality: A challenge for feminist geography. The Professional G eographer, 59, 10-21. https:/ / doi.org/ 10.1111/ j.1467-9272.2007.00587.x

Valentine, G . (2008). Living with difference: Reflections on geographies of encounter. Progress in H uman G eography, 32, 323-337. https:/ / doi.org/ 10.1177/ 0309133308089372

Weheliye, A. (2014). H abeus viscus: Racializing assemblages, biopolitics, and black feminist theories of the human. D urham, NC: D uke University Press. 
Wilson, H. (2016). Encountering Havana: Texts, aesthetics, and documentary encounters. In J. D arling, \& H. Wilson (Eds.), E noountering the aity (pp. 203-220). Milton Park, UK: Routledge.

Wilson, H. (2017). On geography and encounter: Bodies, borders, and difference. Progress in $\mathrm{H}$ uman G eography, 41, 451-471. https:/ / doi.org/ 10.1177/ 0309132516645958

Wilson, H., \& D arling, J. (2016). The possibilities of encounter. In J. D arling, \& H. Wilson (Eds.), E noountering the city (pp. 1-24). Milton Park, UK: Routledge.

Ye, J. (2016). The ambivalence of familiarity: Understanding breathable diversity through fleeting encounters in Singapore's Jurong West. A rea, 48, 77-83. https:/ / doi.org/ 10.1111/ area.12237 